\title{
New and noteworthy orchid records from Buru Island, Maluku Archipelago
}

\author{
W.A. Mustaqim ${ }^{1,2} \&$ I.P. Astuti ${ }^{3}$ \\ ${ }^{1}$ Plant Biology Graduate Program, Department of Biology, \\ Faculty of Mathematics and Natural Science, Institut Pertanian Bogor, \\ Dramaga, Bogor 16680, Jawa Barat, Indonesia. \\ wendyachmmadm@gmail.com \\ ${ }^{2}$ Botany Division, Generasi Biologi Indonesia (Genbinesia) Foundation, \\ Jl. Swadaya Barat No. 4, Gresik Regency 61171, \\ Jawa Timur, Indonesia \\ ${ }^{3}$ Center for Plant Conservation-Bogor Botanical Garden, \\ Indonesian Institute of Sciences, Jln. Ir. H. Djuanda 13, \\ Bogor, Jawa Barat, Indonesia. \\ inggit.pa@gmail.com
}

\begin{abstract}
A short note on the orchids of Buru Island, Maluku Archipelago, is presented. Bulbophyllum cruciatum J.J.Sm. and Dendrobium bicaudatum Reinw. ex Lindl. are new records for Buru. Trichotosia buruensis (J.J.Sm.) S.Thomas et al. has been rediscovered after a lapse of 84 years. The distribution of a species with a previously uncertain distribution in Maluku, Dilochia wallichii Lindl., is now confirmed for Buru. We also discovered a population of the endemic Vanda saxatilis J.J.Sm. All species are briefly discussed and illustrated by photographs.
\end{abstract}

Keywords. Eastern Malesia, Orchidaceae, rediscovery

\section{Introduction}

The orchid flora of the Maluku Archipelago is poorly known (Thomas \& Schuiteman, 2002). Since the publication of pioneering studies in the early twentieth century, such as those by Smith $(1905,1926,1928)$, no further comprehensive taxonomic studies have been carried out, although there has been a recent checklist which includes this region by Thomas \& Schuiteman (2002).

Buru is the third largest island in the Maluku Archipelago. A large portion of the area consists of undulating terrain, much of it still covered by pristine rainforest (Fig. 1). There is a nature reserve located in the southeastern part of the island called Masbait Nature Reserve (established in 1985). However, it only covers a small part of the rainforest present on the island and the unprotected areas have been subject to logging and road construction.

The entire flora of Buru is under-sampled and not just the orchids. When exploration and research is undertaken new additions to the flora of this island are found, for example Mustaqim (2017, 2018) and Mustaqim et al. (2018). During a short expedition to explore the orchids of Buru Island, we discovered a few noteworthy plants, two of which were found to be new records for Buru. 


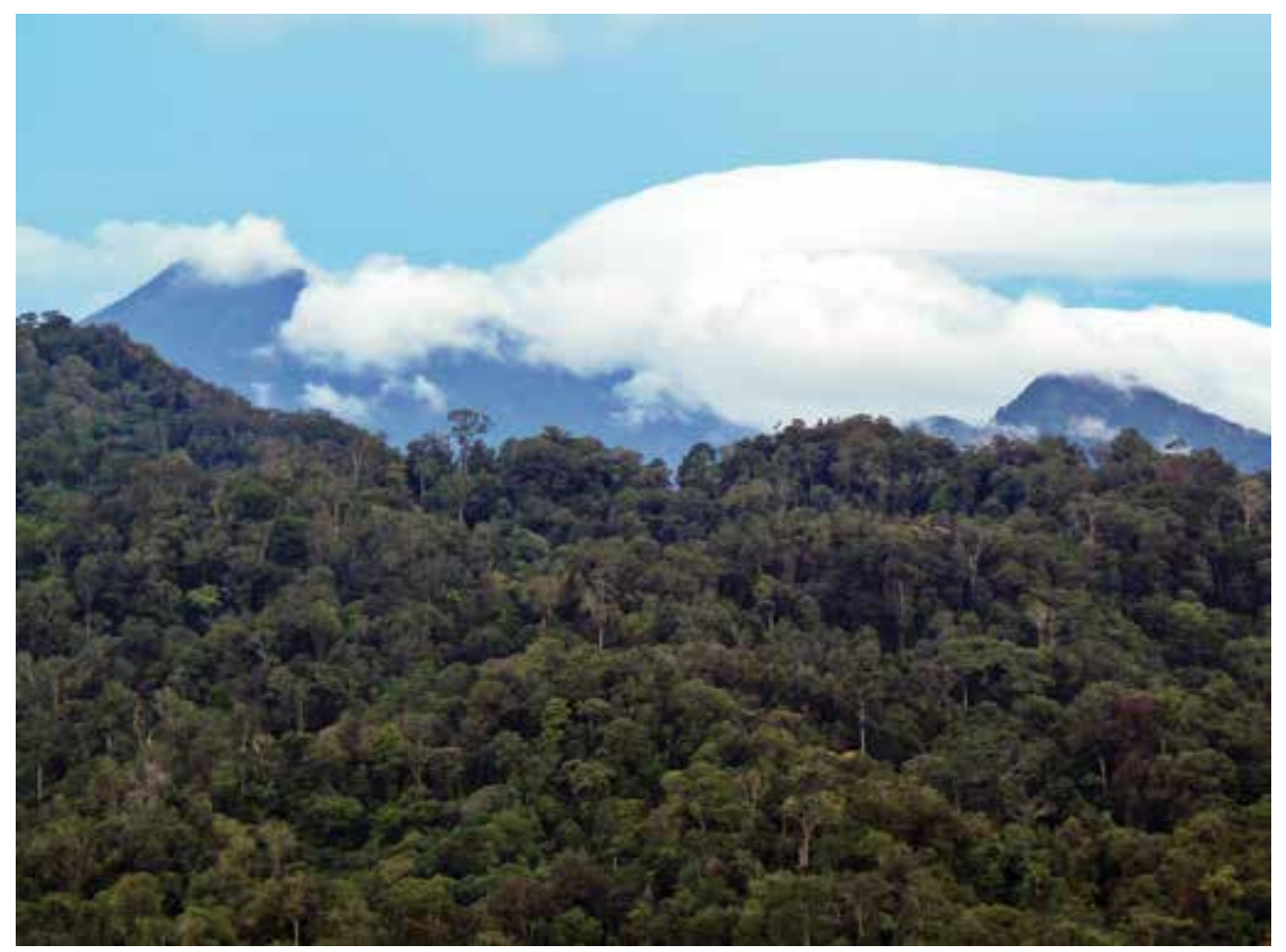

Fig. 1. An example of the landscape of Buru Island. Most of this forest has not previously been visited by botanists (Photo: W.A. Mustaqim).

\section{New records}

\section{Bulbophyllum cruciatum J.J.Sm. (Fig. 2)}

Prior to our discovery, this species was only known from New Guinea (De Vogel et al., 2014; Govaerts et al., 2018) and Seram Island (recorded as Bulbophyllum immobile Schltr.; Mursidawati et al., 1999). The Seram record by Mursidawati et al. (1999) was overlooked by Thomas \& Schuiteman (2002) who published a list of orchids of Sulawesi and Maluku Archipelago. Our record from Buru Island represents the westernmost occurrence of the species. The distribution of this species in the Maluku Archipelago is shown in Fig. 3.

This species can be recognised by its compressed conical and moniliform pseudobulb which is $1.9-2.4 \mathrm{~cm}$ diam., the short inflorescence bearing a single flower borne on a very short peduncle (c. $0.4 \mathrm{~cm}$ long), a cruciate flower with sepals purple striate, the dorsal sepal lanceolate and concave and the lateral ones obliquely oblongovate, petals much smaller than the sepals and falcate, lip immobile, ligulate, at the base with two incurved auricles, column curved with two subulate auricles at the apex, and pedicellate ovary (Smith, 1911). The flower of the plant from Buru is roughly half the size as that given in the protologue except for the petal length (1.5 vs $2 \mathrm{~mm}$ long or 


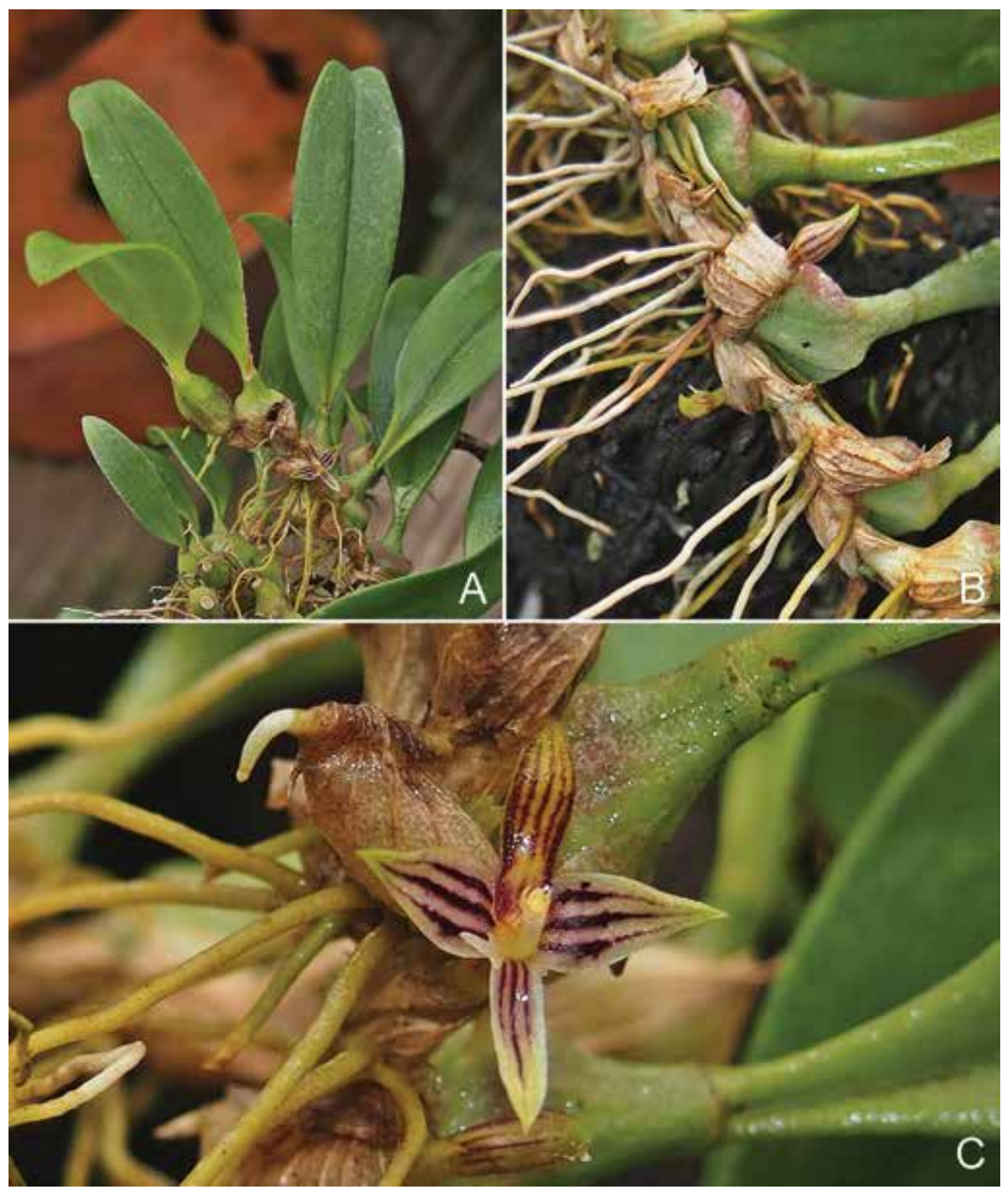

Fig. 2. Bulbophyllum cruciatum J.J.Sm. A. Habit. B. Rhizome, pseudobulbs and flower buds. C. Fully open flower. All from Buton 25 (KRB). (Photos: W.A. Mustaqim).

about $3 / 4$ times) (Smith, 1911). With this floral morphology, the plant would previously have been identified as Bulbophyllum immobile, a species which is now treated as a synonym of Bulbophyllum cruciatum (De Vogel et al., 2014).

Specimen examined. INDONESIA: Maluku: Buru Island, Buru Regency, Fena Leisela District, Wasbakat village, c. 100 m, 11-12 Mar 2014, Buton 25 (KRB [also living collection B99709236]). 


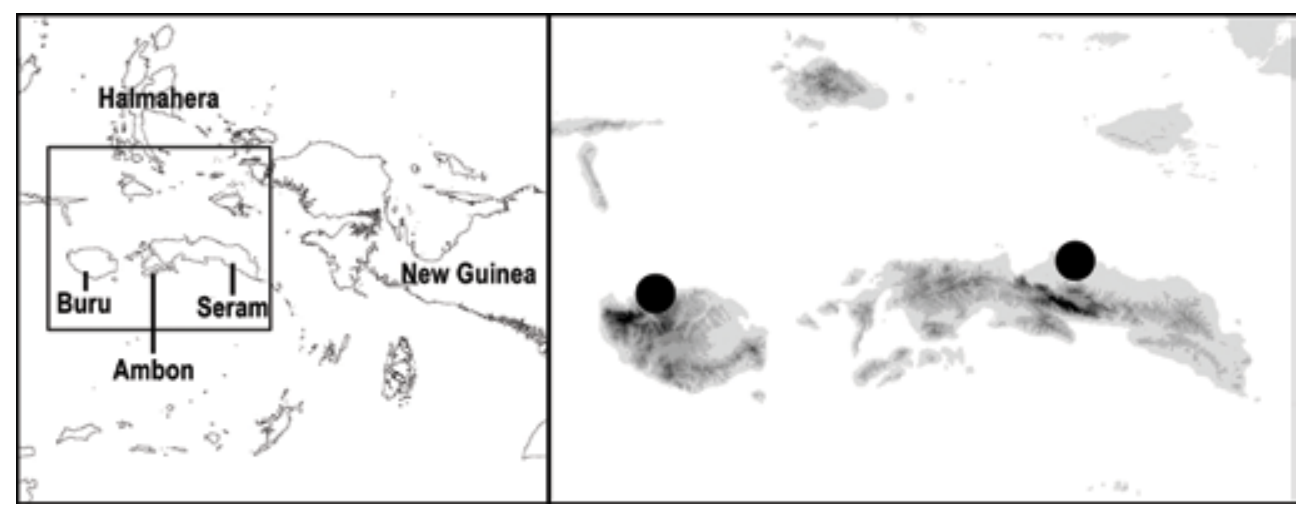

Fig. 3. Distribution of Bulbophyllum cruciatum J.J.Sm. in the Maluku Archipelago.

2. Dendrobium bicaudatum Reinw. ex Lindl. (Fig. 4)

In the latest revision of Dendrobium sect. Spatulata, Cribb (1986) listed the distribution of this species in the Maluku Islands (Moluccas) as Sula, Seram, and Ambon, but not on Buru. We have found this species growing epiphytically in lowland forest with scattered trees. Based on Cribb (1986), Dendrobium bicaudatum can be distinguished from other species of Dendrobium sect. Spatulata by the dorsoventral leaves, the tubular rachis sheath, a mid-lobe of the lip that is broader than the length and 7-9 $\mathrm{mm}$ long mentum. Our specimen differs slightly in having a mid-lobe that is larger (c. $1.1 \times 1.6 \mathrm{~cm}$ vs $0.4 \times 1 \mathrm{~cm})$, a larger $\operatorname{lip}(2.55 \times 2 \mathrm{~cm}$ vs up to $1.8 \times 1.5 \mathrm{~cm})$ and a longer column ( 7.5 vs up to $7 \mathrm{~mm}$ long). In addition, the petals are up to 2-times (or even 3-times in the early fruiting stage (Fig. 4B)) twisted which is a character associated with the related Dendrobium antennatum Lindl. (Cribb, 1986), leading to some confusion. However, we consider that the degree of twisting is related to the age of the flower and is not of taxonomic significance. A thorough morphological comparison places our material, at least tentatively, in Dendrobium bicaudatum.

Specimen examined: INDONESIA: Maluku: Buru Island, Buru Regency, Air Buaya District, south of Bara Village, near road to Pasir Putih ( $\left.3^{\circ} 9^{\prime} 12.9^{\prime \prime} \mathrm{S} 126^{\circ} 15^{\prime} 4.2^{\prime \prime} \mathrm{E}\right), 80 \mathrm{~m}, 21$ May 2014, Mustaqim 245 (BO).

\section{Rediscovery}

1. Trichotosia buruensis (J.J.Sm.) S.Thomas, Schuit. \& de Vogel (Fig. 5A-B)

This epiphytic species is endemic to Buru Island. It was previously known only from the type collection, but a plant collected from Buru and grown on in Bogor Botanical Garden has been identified as this species after a lapse of 84 years. This species was originally described as Eria buruensis J.J.Sm. (Smith, 1926) but in Thomas \& Schuiteman (2002) it was transferred to the genus Trichotosia. 

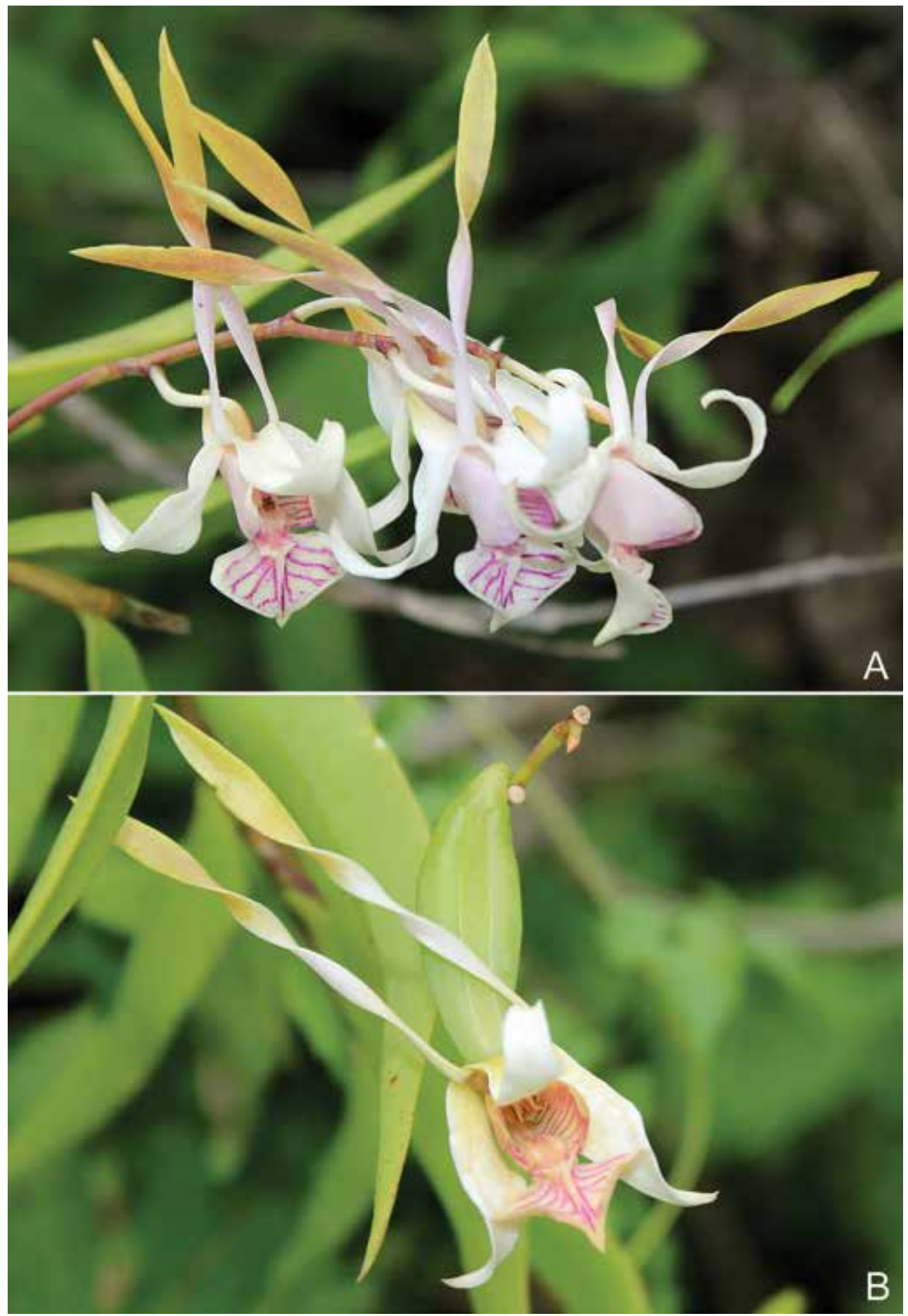

Fig. 4. Inflorescence of Dendrobium bicaudatum Reinw. ex Lindl. A. Full anthesis. B. Late stage. All from Mustaqim 245 (BO). (Photo: W.A. Mustaqim). 

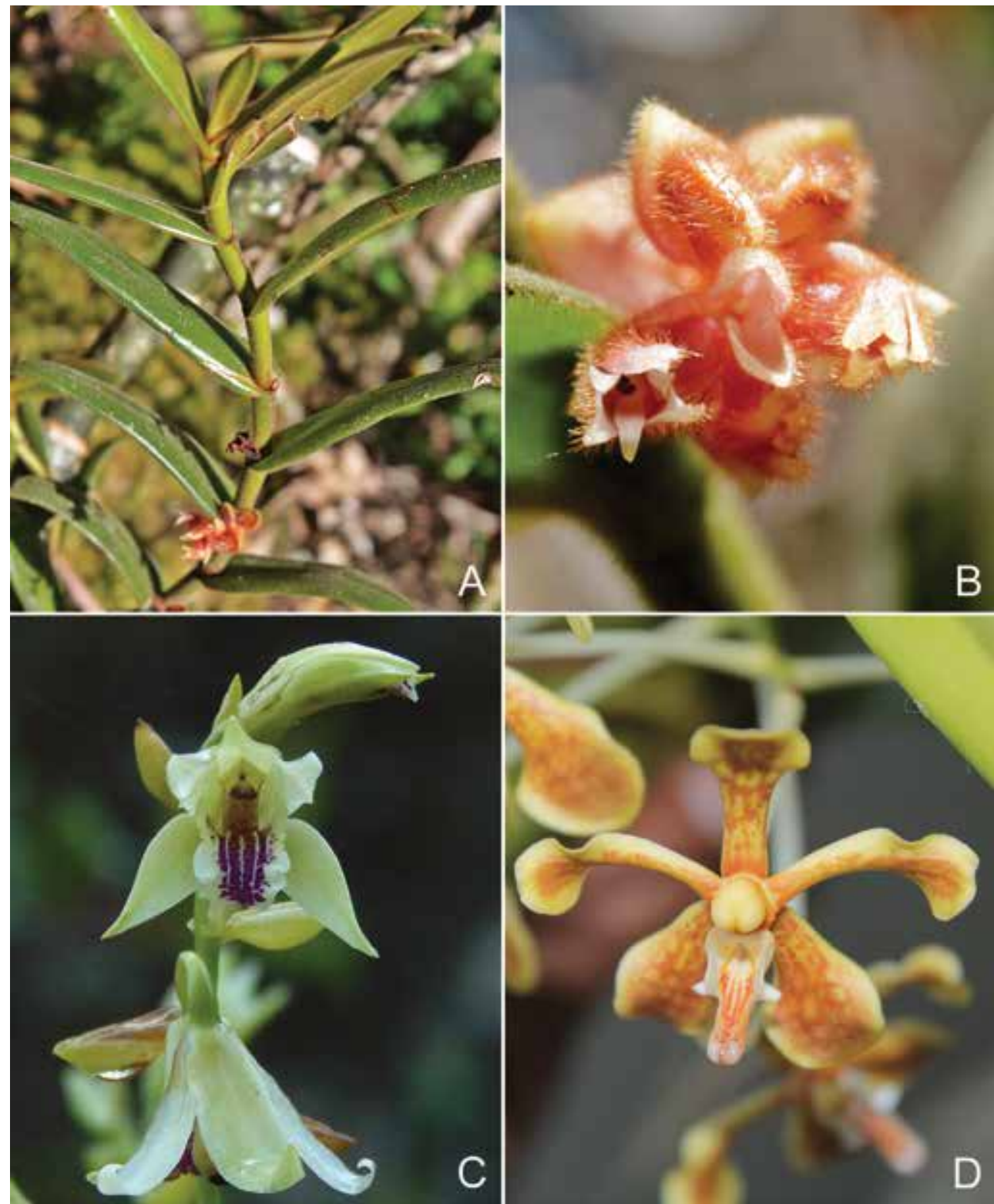

Fig. 5. A \& B. Trichotosia buruensis (J.J.Sm.) S.Thomas et al. A. Habit. B. Flowers. C. Flowers of Dilochia wallichii Lindl. D. Flower of Vanda saxatilis J.J.Sm. A-B from Mustaqim 170 (BO); C from Mustaqim 259 (BO) and D from Mustaqim 205 (BO). (Photos: A-C: W.A. Mustaqim; D: A.P.N. Muda).

The collection locality of this orchid is close to a recently constructed road. Illegal logging has not yet reached this area but there is already much destruction in the northern part of Buru and the presence of a road may increase future illegal logging. 
Specimen examined. INDONESIA: Maluku: Buru Island, Buru Regency, Fena Leisela District, near Waereman (3²3'5.8"S 126 33'5.9"E), 881 m, 22 Mar 2014, Mustaqim 170 (KRB).

\section{Noteworthy species}

\section{Dilochia wallichii Lindl. (Fig. 5C)}

This species is distributed in Thailand and Malesia. In Malesia, it is found from Peninsular Malaysia, Sumatra, Borneo and Java to New Guinea (Sulistiarini, 2012). However, Thomas \& Schuiteman (2002) noted that its distribution in Maluku is uncertain. During a revision of the Indonesian species of Dilochia, Sulistiarini (2012) did not mention any material from the Maluku Archipelago. Recently, a plant of this species was collected from the central part of Buru Island. It was found growing terrestrially on the margin of a recently built road at an elevation of around $967 \mathrm{~m}$ above sea level.

This species can be recognized in the field particularly by its thick, shining, elliptic and rigidly coriaceous leaves with blades more than $2 \mathrm{~cm}$ wide. The floral bract length/width index is c. 2 times. The greenish-yellow flowers have a lip with the epichile shorter than the hypochile; the column lacks a column-foot and the upper margins are widened and wing-like (Sulistiarini, 2012).

Specimens examined. INDONESIA: Maluku: Buru Island, Buru Regency, Fena Leisela

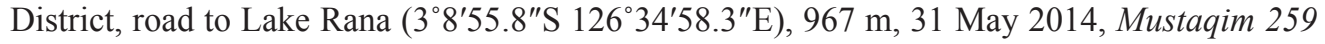
(BO).

\section{Vanda saxatilis J.J.Sm. (Fig. 5D)}

The endemic Vanda saxatilis is a highly ornamental species. We have recorded at least five individuals (we are sure that there are many more plants we did not encounter) growing safely in a sacred forest which is rarely visited by local people. We have withheld the exact locality since this species is very attractive and subjected to illegal collecting. We have successfully transferred two living individuals to Bogor Botanical Gardens, Jawa Barat, accompanied by herbarium material. This species has been confused with Vanda furva (L.) Lindl., but is readily distinguished by the cylindrical, not strongly basally widened, column and by the presence of narrow, patent side-lobes to the lip (Motes et al., 2015).

Specimen examined. INDONESIA: Maluku: Buru Island, 18 m, 24 Apr 2014, Mustaqim 205 (BO).

ACKNOWLEDGEMENTS. We are grateful to Major General Agus Sutomo, chief commander of Ekspedisi NKRI Koridor Maluku and Maluku Utara 2014 for the support of our field 
expedition on Buru Island, and also to Capt. Dedy D. Cahyadi for invaluable support in the field. Also to La Herman Buton for the donation of a specimen, Ayu Muda for the photograph of Vanda saxatilis, and Taofik Hidayat, Zendi T. Rahardioko, I Nyoman Putra Arnawa, Alwinsyah Lubis and Koirunnisa M. Fatwa for help in the field. Also to the local people of Buru Island who kindly accepted us and gave permission for orchid collecting. The first author is indebted to Destario Metusala for the confirmation of the identification of the Vanda specimen.

\section{References}

Cribb, P.J. (1986). A revision of Dendrobium sect. Spatulata (Orchidaceae). Kew Bull. 41(3): 615-692.

De Vogel, E., Vermeulen, J. \& Schuiteman, A. (2014). Flora Malesiana: Orchids of New Guinea. Naturalis Biodiversity Center, Leiden, The Netherlands. https://orchidsnguinea. linnaeus.naturalis.n1/. Accessed 17 Sep. 2018.

Govaerts, R., Bernet, P., Kratovchil, K., Gerlach, G., Carr, G., Alrich, P., Pridgeon, A.M., Pfahl, J., Campacci, M.A., Holland Baptista, D., Tigges, H., Shaw, J., Cribb, P., George, A., Kreuz, K. \& Wood, J. (2018). World checklist of Orchidaceae. Facilitated by the Royal Botanic Gardens, Kew. Available from http://wcsp.science.kew.org/. Accessed 17 Sep. 2018.

Motes, M, Gardiner, L.M. \& Roberts, D.L. (2015). Vanda section Dactylolobatae: A summary, two new species, and a key to identification. Orchid Digest 79(2): 98-104.

Mursidawati, S., Norton, D.A. \& Astuti, I.P. (1999). Distribution of Pomatocalpa spicata Breda (Orchidaceae) within and among host trees in Manusela National Park, Seram, Maluku Archipelago, Indonesia. Selbyana 20(1): 116-119.

Mustaqim, W.A. (2017). Agalmyla inaequidentata (Hilliard) B.L. Burtt (GesneriaceaeDidymocarpoideae): A new genus record for Buru Island, Maluku, Indonesia. Biodiversitas 18(3): 1062-1065.

Mustaqim, W.A. (2018). Codonobea kjellbergii (Gesneriaceae) in Buru Island, Maluku: a new genus record for the island. J. Trop. Biol. Conserv. 15: 97-100.

Mustaqim, W.A., Astuti, I.P. \& Rahayu, S. (2018). Hoya anulata (Apocynaceae: Asclepiadoideae): a new record for Maluku, Indonesia. Telopea 21: 161-165.

Smith, J.J. (1905). Die Orchideen von Ambon. Batavia: Landsdrukkerij.

Smith, J.J. (1911). Vorläufige Beschreibungen neuer papuanischer Orchideen. III. Bull. Dépt. Agric. Indes Néerl. 45: 1-25.

Smith, J.J. (1926). Orchidaceae Buruensis. Bull. Jard. Bot. Buitenzorg ser. 3, 9: 439-481.

Smith, J.J. (1928). Orchidaceae Seranensis. Bull. Jard. Bot. Buitenzorg ser. 3, 10: 85-172.

Sulistiarini, D. (2012). The orchid genus Dilochia in Indonesia. Reinwardtia 13(4): 379-387.

Thomas, S. \& Schuiteman, A. (2002). Orchids of Sulawesi and Maluku: a preliminary catalogue. Lindleyana 17: 1-74. 